\title{
New rhizobia strains isolated from the Amazon region fix atmospheric nitrogen in symbiosis with cowpea and increase its yield
}

Paulo Ademar Avelar Ferreira ${ }^{1,2}$, João Paulo Andrade Rezende Pereira ${ }^{1}$,

Dâmiany Pádua Oliveira ${ }^{1}$, Helson Mário Martins do Vale ${ }^{1,3}$, Ederson da Conceição Jesus ${ }^{1,4}$, André Luís de Lima Soares ${ }^{1}$, Cláudia de Oliveira Gonçalves Nogueira1,5, Messias José Bastos de Andrade $^{6}$, Fatima Maria de Souza Moreira ${ }^{1 \star}$

1.Universidade Federal de Lavras - Departamento de Ciência do Solo - Lavras (MG), Brazil.

2.Universidade Federal de Santa Maria - Departamento de Ciência do Solo - Santa Maria (RS), Brazil.

3.Universidade de Brasília - Departamento de Fitopatologia - Brasília (DF), Brazil.

4.Empresa Brasileira de Pesquisa Agropecuária - Centro Nacional de Pesquisa de Agrobiologia - Seropédica (RJ), Brazil. 5.Centro Universitário de Formiga - Departamento de Cências Biológicas - Formiga (MG), Brazil

6.Universidade Federal de Lavras - Departamento de Agricultura - Lavras (MG), Brazil.

ABSTRACT: Studies in the Amazon indicate a wide diversity of rhizobia with the ability for biological nitrogen fixation (BNF), which could expand the number of strains approved for cowpea. Thus, the aim of this field study was to evaluate the agronomic performance in cowpea of the several strains isolated from the soils of the Brazilian states Acre and Rondônia, and to compare them with strains approved by the Ministry of Agriculture (MAPA) and with non-inoculated controls (without and with mineral nitrogen fertilizer). The inoculants performed well. Though less effective than the other strains, the UFLA 03-36 strain also was prominent with respect to grain yield. Because of the positive response of the UFLA 03-129 strain, which led to yield increases greater than the obtained from the control without inoculation plus mineral-N, it can be recommended as an inoculum for cowpea. Further investigations should be carried out to obtain MAPA's approval for their use. Other experiments involving this strain and several cultivars are being carried out on other types of soil and environmental conditions of the state of Minas Gerais.

Key words: Vigna unguiculata, biological nitrogen fixation, Amazon strains, seed inoculation. 
Results of various studies in the field confirm the benefits of BNF for cowpea (Lacerda et al. 2004; Soares et al. 2006; 2014; Costa et al. 2011; Farias et al. 2016). This process allows substitution (partial or even total) of the use of nitrogen fertilizers, which not only reduces costs and environmental damage (from the use of fossil fuels in obtaining mineral $\mathrm{N}$ and from the negative effects of poor use of this fertilizer), but also increases yields (Moreira et al. 2016). ${ }^{6}$ However, native rhizobia soil population may not be sufficient to significantly increase yields of this legume species and so the use of inoculant containing strains that are more effective in the BNF process is necessary. However, for this biotechnology to be successful, careful selection of strains with ability to compete with those already established in the soil and with a high $\mathrm{N}_{2}$ fixation efficiency is required. In addition to these characteristics, the strains introduced should have tolerance to high temperatures and to soil acidity, conditions that are predominant in Amazon soils, from where most of the strains approved by MAPA for cowpea have been selected (Soares et al. 2006; 2014; Zilli et al. 2008).

The Amazon region is considered to have great potential in holding a wide diversity of rhizobia of interest for $\mathrm{BNF}$ in cowpea. In this respect, other rhizobia have been isolated in various land use systems of the Amazon, with good results obtained for strains UFLA 03-36, and UFLA 03-129 under greenhouse and field conditions (Lacerda et al. 2004; Soares et al. 2006; 2014; Costa et al. 2011; Farias et al. 2016). The possibility of approval of these new strains would expand the number of inocula for the crop. Thus, the aim of this study was to evaluate the effectiveness of new strains of Bradyrhizobium spp. isolated from Amazon soils in symbiosis with cowpea.

A field experiment was conducted in the rainy crop season in a Latossolo Vermelho Amarelo distrófico (Oxisol - USDA classification) of the municipality of Iguatama, in the west center of Minas Gerais state, Brazil (206'53.7” S, 4541'55.7” W). The soil chemical characteristics were $\mathrm{pH}=5.9, \mathrm{P}=2.0 \mathrm{mg} \cdot \mathrm{dm}^{-3}($ MehlichI), $\mathrm{K}=64.0 \mathrm{mg} \cdot \mathrm{dm}^{-3}, \mathrm{Ca}=2.2 \mathrm{cmol}_{\mathrm{c}} \cdot \mathrm{dm}^{-3}, \mathrm{Mg}=1.6 \mathrm{cmol}_{\mathrm{c}} \cdot \mathrm{dm}^{-3}$, $\mathrm{Al}=0.2 \mathrm{cmol}_{\mathrm{c}} \cdot \mathrm{dm}^{-3}, \mathrm{H}+\mathrm{Al}=3.2 \mathrm{cmol}_{\mathrm{c}} \cdot \mathrm{dm}^{-3}, \mathrm{SB}=4.0 \mathrm{cmol}_{\mathrm{c}} \cdot \mathrm{dm}^{-3}$, $\mathrm{T}=7.2 \mathrm{cmol}_{\mathrm{c}} \cdot \mathrm{dm}^{-3}, \mathrm{~V}=55.4 \%$, and organic matter $=2.1 \mathrm{dag} \cdot \mathrm{kg}^{-1}$. The native rhizobia population capable of nodulating the crop

${ }^{6}$ Moreira, F. M .S., Oliveira, D. P., Rufini, M., Soares, B. L., Guimarães, A. A., Costa, E. M. and Andrade, M. J. B. (2016). Inoculação com estirpes selecionadas de rizóbio aumenta a produtividade de feijão-comum e caupi. In: Memorias del XXI Congreso Latinoamericano de la ciencia del suelo: todos los suelos en la mitad del mundo; Quito, Ecuador. was approximately $5.08 \times 10^{3} \mathrm{CFU} \mathrm{g} \cdot$ soil $^{-1}$ estimated with the same methodology as Soares et al. (2014). The climate records made available by the Brazilian Meteorological Institute throughout the trial indicated a mean temperature of $22.5^{\circ} \mathrm{C}$ and mean rainfall of $277 \mathrm{~mm} \cdot \mathrm{month}^{-1}$, which was less intense at sowing $(186 \mathrm{~mm})$ and harvest $(237 \mathrm{~mm})$ and more concentrated during the grain filling period $(436 \mathrm{~mm})$. The experiment site had previously been cultivated for several years with a soybean/maize/edible bean rotation, and cowpea had never been planted before.

The experimental design consisted of randomized blocks with six replications and six treatments, involving four levels of seed peat inoculation and two non-inoculated controls: one without and another with $155 \mathrm{~kg}$ urea $\cdot \mathrm{ha}^{-1}$ (that equivalent to $70 \mathrm{~kg} \mathrm{~N} \cdot \mathrm{ha}^{-1}$ ), half applied at sowing and the other half topdressed at 20 days after emergence. The strains UFLA 03-129 and UFLA 03-36 were selected for their high effectiveness in Leonard jars, soil pots, and in the field (Lacerda et al. 2004; Lima et al. 2005; Soares et al. 2006). The UFLA 03-129 and UFLA 03-36 were compared to the strains UFLA 03-84 and INPA 03-11B, already approved by MAPA as inocula for cowpea. A more detailed description of the strains is presented in Table 1.

The inoculant were prepared with peat sterilized in an autoclave, mixed at a ratio of $3: 1(w: v)$ with log phase cultures in a semisolid 79 medium (Fred and Waksman 1928), according to the procedures described by Soares et al. (2006). The resulting material was applied at $25 \mathrm{~g}$ per kg of seeds. The quality of the inoculant was monitored by counting the colony-forming units (CFU) and by comparing it to the legal minimum number of viable cells, approximately $10^{9} \mathrm{CFU}$ per gram of inoculant, at planting (Brasil 2011). The final concentration of rhizobial cells was about $10^{6} \mathrm{CFU}$ per seed.

Each experimental unit $\left(36 \mathrm{~m}^{2}\right)$ consisted of six 6-m length rows spaced at $1.0 \mathrm{~m}$, with a useful plot area corresponding to the four center rows. Soil preparation was done by a soil plowing, harrowing, and lines demarcations. Rows 1 and 6 were considered border rows, rows 2 and 3 used for sampling at flowering, and rows 4 and 5 used for harvest at maturation. The planting furrows of all the plots were fertilized with $350 \mathrm{~kg}$ simple superphosphate $\cdot \mathrm{ha}^{-1}$ and $150 \mathrm{~kg}$ potassium chloride $\cdot \mathrm{ha}^{-1}$ (equivalent to $70 \mathrm{~kg} \mathrm{P}_{2} \mathrm{O}_{5} \cdot \mathrm{ha}^{-1}$ and $40 \mathrm{~kg} \mathrm{~K}_{2} \mathrm{O} \cdot \mathrm{ha}^{-1}$, respectively). Immediately after inoculation, seeds from the Poços de Caldas cowpea cultivar were manually sown at a density of 10 seeds per meter. This cultivar was chosen as the only one among 24 genetic 
materials launched between 1990 and 2015 in Brazil, with recommendations for the Southeast region of the country, specifically for the Zona da Mata of the state of Minas Gerais. It is well known the influence of variety, environmental conditions and soil type in plant nutrition depending on both soil fertility and biological processes (usually symbiotic nitrogen fixation). Usually, cowpea varieties are quite responsive in diverse conditions (Marinho et al. 2014; Alcantara et al. 2014). Thus, is more important to test varieties adapted to soil conditions as it was in our study. Even because when the plant is fine the symbiosis is also fine.

At flowering a 10-plant sample was removed at random for determination of the number of nodules (NN) and nodule dry matter (NDM), shoot dry matter (SDM), shoot $\mathrm{N}$ concentration (SNC), and shoot $\mathrm{N}$ accumulation (SNA). At grain maturity, grain yield (GY), grain $\mathrm{N}$ concentration (GNC), and grain N accumulation (GNA) were determined. Grain yield was corrected to $130 \mathrm{~g} \cdot \mathrm{kg}^{-1}$ moisture and calculated based on threshing the pods from all the plants of the rows 4 and 5 . The $\mathrm{N}$ concentration was determined by the semi-micro Kjeldahl method. The $\mathrm{N}$ accumulated in the shoots was calculated by multiplying the SDM by the SNC and dividing by 100 . The GNC and GNA were determined adopting the same methodology used for the shoot samples, substituting the SDM values for those of the GY.

All data were subjected to analysis of variance using the Sisvar software (Ferreira 2011) after being previously subjected to normality (Shapiro-Wilks test) and variance homocedasticity (Bartlett test) tests, using the R software (R Development Core Team 2011). The NN and NDM variables were first transformed into $(x+1)^{0.5}$ in order to meet the requirements of analysis of variance. In cases of significant effect of the treatments, means were grouped by the Scott-Knott test $(\mathrm{p}<0.05)$; all analyses were performed using Sisvar software.

In general, the inoculations resulted in high nodulation rates (NN and NDM), with NDM considerably higher than that of the treatment without inoculation and without mineral $\mathrm{N}$ (Table 2). This indicates that although native strains were present in the soil (NN, Table 2), they were not as effective in production of nodular matter as the introduced strains, which certainly limited BNF and negatively affected the other variables, above all grain yield (Table 2). Under conditions of low density of effective rhizobia or of abundant native populations that are not very effective, the effect of inoculation becomes even more evident (Soares et al. 2006; 2014; Oliveira et al. 2017), which explains the mean data registered.

Table 1. Origin and crop characteristics of the rhizobia strains used in the study as inocula for cowpea.

\begin{tabular}{|c|c|c|c|c|c|}
\hline \multirow{2}{*}{ Strains } & \multirow{2}{*}{ Land use, municipality, state, country } & \multicolumn{4}{|c|}{ Growth characteristics in 79 medium } \\
\hline & & $\mathbf{A C l}^{1}$ & $\mathbf{P G}^{2}$ & pH & $\mathrm{COL}^{3}$ \\
\hline UFLA 03-36 & Fallow, Theobroma, RO, BR & 4 & High & Neutral & White \\
\hline UFLA 03-84 & Pasture, Jí-Paraná, RO, BR & 6 & Medium & Alkaline & White \\
\hline UFLA 03-129 & Pasture, Pedro Peixoto, AC, BR & 7 & Medium & Neutral & Yellow \\
\hline INPA 03-11B & Land not subject to flooding, Manaus, AM, BR & 7 & Medium & Alkaline & White \\
\hline
\end{tabular}

${ }^{1}$ Time in days of growth of isolated colonies, ${ }^{2}$ Gum production, and ${ }^{3}$ Color of the colonies.

Table 2. Mean values of the number of nodules (NN), nodule dry matter (NDM) per plant, shoot dry matter (SDM), shoot N concentration (SNC) and grain N concentration (GNC), shoot N accumulation (SNA), grain N accumulation (GNA), and grain yield (GY) in cowpea as a function of inoculation treatments (Rhizobia strains) and two control treatments without inoculation [(CwtN-without $\mathrm{N}$ fertilizer and CwN-with $\mathrm{N}$ fertilizer (150 kg urea $\left.\cdot \mathrm{ha}^{-1}\right)$ ] in cowpea.

\begin{tabular}{|c|c|c|c|c|c|c|c|c|}
\hline N sources & $\mathbf{N N}^{1}$ & $\begin{array}{c}\text { NDM }^{1} \\
\left(m g \cdot p l a n t^{-1}\right)\end{array}$ & $\begin{array}{c}\text { SDM } \\
\left(\mathbf{g} \cdot \text { plant }^{-1}\right)\end{array}$ & $\begin{array}{l}\text { SNC } \\
(\%)\end{array}$ & $\begin{array}{c}\text { SNA } \\
\left(m g \cdot \text { plant }^{-1}\right)\end{array}$ & $\begin{array}{l}\text { GNC } \\
(\%)\end{array}$ & $\begin{array}{c}\text { GNA } \\
\left(\mathbf{k g} \cdot h \mathbf{a}^{-1}\right)\end{array}$ & $\begin{array}{c}\text { GY } \\
\left(k_{g} \cdot h a^{-1}\right)\end{array}$ \\
\hline UFLA 03-36 & $17 \mathrm{~A}$ & $71.7 \mathrm{~A}$ & $14.2 \mathrm{~B}$ & $3.3 \mathrm{~B}$ & $473.4 \mathrm{~B}$ & $3.2 \mathrm{~B}$ & 19.6 D & $630 \mathrm{C}$ \\
\hline UFLA 03-129 & $16 \mathrm{~A}$ & $67.5 \mathrm{~A}$ & $15.9 \mathrm{~B}$ & $3.5 \mathrm{~B}$ & $556.4 \mathrm{~B}$ & $3.2 \mathrm{~B}$ & $26.4 \mathrm{C}$ & 880 B \\
\hline UFLA 03-84 & $17 \mathrm{~A}$ & $54.8 \mathrm{~A}$ & $17.3 \mathrm{~A}$ & $3.7 \mathrm{~A}$ & $639.2 \mathrm{~B}$ & $3.7 \mathrm{~A}$ & $38.5 \mathrm{~B}$ & $1,140 \mathrm{~A}$ \\
\hline INPA 03-11B & $17 \mathrm{~A}$ & $68.8 \mathrm{~A}$ & $18.2 \mathrm{~A}$ & $3.6 \mathrm{~A}$ & $650.2 \mathrm{~A}$ & $3.9 \mathrm{~A}$ & $44.3 \mathrm{~A}$ & $1,160 \mathrm{~A}$ \\
\hline CwtN & $17 \mathrm{~A}$ & $60.2 \mathrm{~B}$ & $13.4 \mathrm{~B}$ & $3.1 \mathrm{~B}$ & 405.6 B & $2.9 \mathrm{~B}$ & 15.1 D & 570 D \\
\hline CwN & $15 B$ & $42.5 \mathrm{~B}$ & $18.5 \mathrm{~A}$ & $4.0 \mathrm{~A}$ & $743.6 \mathrm{~A}$ & $4.0 \mathrm{~A}$ & $45.1 \mathrm{~A}$ & $1,170 \mathrm{~A}$ \\
\hline
\end{tabular}

Within each column, mean values followed by the same letters are significantly equivalent $(p<0.05)$ according to the Scott-Knott test. ${ }^{1} \mathrm{Clustering}$ obtained from data transformed in $(x+1)^{0.5}$. 
Although the mineral N supplied in the soil reduced the NN produced by the native population as inferred based on data from the control with urea $\mathrm{N}$, the intensity of this negative effect did not drastically compromise establishment of this symbiosis, allowing formation of nodules with weight similar to that of the absolute control (without inoculation and without mineral N) (Table 2).

The most relevant finding, however, is in regard to the performance of the inoculations, especially those with the strains UFLA 03-129, UFLA 03-84, and INPA 03-11B. This indicates that not only are the selected strains able to compete with native strains for the infection site (NDM higher than both controls, Table 2), but these were also more effective in BNF than the native populations. These characteristics are indispensable to obtain satisfactory yields, such as those observed in the present study - much higher than the Brazilian average - $506 \mathrm{~kg} \cdot \mathrm{ha}^{-1}$ reported for cowpea by the Brazilian agricultural statistical service in 2016 (CONAB 2017) (Table 2). The good response of the two reference strains was already expected, corroborating their approval by MAPA as inocula for cowpea. In turn, the good response of the UFLA 03-129 strain, still in the selection phase, is evident. Lacerda et al. (2004) showed the symbiotic and agronomic competence of this strain, which produced grain yield $34 \%$ greater than the non-inoculated control. In the current study, this increase is more than 50\% (Table 2). The results of Soares et al. (2006) with this same strain showed even greater differences between treatments, with up to more than double the yield of the absolute control, while also enriching the grain $\mathrm{N}$ content, as observed in the current study. All these findings point to the potential recommendation of the UFLA 03-129 strain as an inoculum for cowpea, and new investigations should be carried out for the purpose of approval from MAPA.

The activity of the UFLA 03-36 strain is also noteworthy, with indication of high competitiveness in nodular infection (Table 2), even though it was not as effective as the other inoculated treatments with respect to $\mathrm{N}_{2}$ fixation. It should also be noted that, although it did not achieve the production levels of the other introduced strains or of the control with $\mathrm{N}$ fertilization, the treatment increased yields by $10 \%$ compared to the control without inoculation and without mineral $\mathrm{N}$ (native population). Considering the results of this strain and of the others, it can be affirmed that the technique of inoculation of cowpea with selected rhizobia strains is a feasible alternative to contribute to increased yields. Other experiments involving rhizobia strains and several cultivars are being carried out on other types of soil and environmental conditions of the state of Minas Gerais.

\section{ACKNOWLEDGMENTS}

We thank the Brazilian National Council for Scientific and Technological Development (CNPq), the Agency for the Improvement of Higher Level Personnel (CAPES), the Research Support Foundation of the State of Minas Gerais (FAPEMIG), and the Ministry of Agriculture, Livestock and Food Supply (MAPA) for research productivity fellowships.

\section{ORCID IDs}

P. A. A. Ferreira

(iD https://orcid.org/0000-0002-5622-6303

J. P. A. R. Pereira

(iD https://orcid.org/0000-0002-9852-3939

D. P. Oliveira

https://orcid.org/0000-0002-1817-4020

H. M. M. Vale

https://orcid.org/0000-0002-5452-3873

E. C. Jesus

iD https://orcid.org/0000-0002-2687-8976

A. L. L. Soares

https://orcid.org/0000-0001-8244-0912

C. O. G. Nogueira

https://orcid.org/0000-0002-1812-3645

M. J. B. Andrade

https://orcid.org/0000-0001-7056-2349

F. M. S. Moreira

https://orcid.org/0000-0003-0159-5811

\section{REFERENCES}

Alcantara, R. M. C. M., Xavier, G. R., Rumjanek, N. G., Rocha, M. M. and Carvalho, J. S. (2014). Eficiência simbiótica de progenitores de cultivares brasileiras de feijão-caupi. Revista Ciência Agronômica, $45,1-9$. 
Brasil (2011). Instrução normativa no 13 de 24 de março de 2011 anexo - protocolo oficial para avaliação da viabilidade e eficiência agronômica de cepas, inoculantes e tecnologias relacionados ao processo de fixação biológica do nitrogênio em leguminosas. Brasília: Diário Oficial da União da República Federativa do Brasil.

[CONAB] Companhia Nacional de Abastecimento (2017). Acompanhamento da safra Brasileira de grãos: safra 2017/18 Primeiro levantamento, Outubro 2017/Companhia Nacional de Abastecimento. Brasília: Conab.

Costa, E. M., Nóbrega, R. S. A., Martins, L. V., Amaral, F. H. C. and Moreira, F. M. S. (2011). Nodulação e produtividade de Vigna unguiculata (L.) Walp por cepas de rizóbio no Polo de produção Bom Jesus, PI. Revista Ciência Agronômica, 42, 1-7.

Farias, T. P., Trochmann, A., Soares, B. L. and Moreira, F. M. S. (2016). Rhizobia inoculation and liming increase cowpea productivity in Maranhão State. Acta Scientiarum. Agronomy, 38, 387-396. https://doi.org/10.4025/actasciagron.v38i3.28630

Ferreira, D. F. (2011). Sisvar: A computer statistical analysis system. Ciência e Agrotecnologia, 35, 1039-1042. https://doi. org/10.1590/S1413-70542011000600001

Fred, E. B. and Waksman, S. A. (1928). Laboratory manual of general microbiology: with special reference to the microorganisms of the soil. New York: McGraw-Hill.

Lacerda, A. M., Moreira, F. M. S., Andrade, M. J. B. and Soares, A. L. L. (2004). Efeito de estirpes de rizóbio sobre a nodulação e produtividade do feijão-caupi. Revista Ceres, 51, 67-82.

Lima, A. S, Pereira, J. P. A. R. and Moreira, F. M. S. (2005). Phenotypic diversity and symbiotic efficiency of Bradyrhizobium spp. strains from Amazonian soils. Pesquisa Agropecuária Brasileira, 40, 1095-1104. https://doi.org/10.1590/S0100-204X2005001100007
Marinho, R. C. N., Nóbrega, R. S. A., Zilli, J. E., Xavier, G. R., Santos, C. A. F., Aidar, S. T., Martins, L. M. V. and Fernandes Júnior, P. I. (2014). Field performance of new cowpea cultivars inoculated with efficient nitrogen-fixing rhizobial strains in the Brazilian Semiarid. Pesquisa Agropecuária Brasileira, 49, 395402. https://doi.org/10.1590/S0100-204X2014000500009

Oliveira, D. P., Figueiredo, M. A., Soares, B. L., Teixeira, O. H. S., Martins, F. A. D., Rufini, M., Chain C. P., Reis, E. P., Morais, A. R., Moreira, F. M. S. and Andrade M. J. B. (2017). Acid tolerant Rhizobium strains contribute to increasing the yield and profitability of common bean in tropical soils. Journal of Soil Science and Plant Nutrition, 17, 922-933. https://doi.org/10.4067/ S0718-95162017000400007

R Development Core Team (2011). R: A language and environment for statistical computing. Vienna: R Foundation for Statistical Computing.

Soares, B. L., Ferreira, P. A. A., Oliveira-Longatti, S. M., Marra, L. M., Rufini, M., Andrade, M. J. B. and Moreira, F. M. S. (2014). Cowpea symbiotic efficiency, $\mathrm{pH}$ and aluminum tolerance in nitrogen-fixing bacteria. Scientia Agricola, 71, 171-180. https:// doi.org/10.1590/S0103-90162014000300001

Soares, A. L. L., Pereira, J. P. A. R., Ferreira, P. A. A., Vale, H. M. M., Lima, A. S., Andrade, M. J. B. and Moreira, F. M. S. (2006). Eficiência agronômica de rizóbios selecionados e diversidade de populações nativas nodulíferas em Perdões (MG). I - caupi. Revista Brasileira de Ciência do Solo, 30, 795-802.https://doi. org/10.1590/S0100-06832006000500005

Zilli, J. E., Xavier, G. R. and Rumjanek, N. G. (2008). BR 3262: Nova estirpe de Bradyrhizobium para a Inoculação de feijãocaupi em Roraima. Boa Vista: Embrapa-Roraima. 